ject advocated by you, Sir,-I mean the public trial, or concours; for this may be advocated on grounds distinct from those of the imputed dishonesty of any party. I would gladly make a few remarks on this important measure, not for the purpose of opposing its adoption in any case, but in order to point out a few difficulties to be met, and to discuss the mechanism by which it is to be worked. I find, however, that this letter has grown already to a considerable length, and that I must aefer all reference to the subject to another communication.

I have now, Sir, only to say, in conclusion, that with a view to assist you and others in arriving at truth, I have detailed some facts, and alluded to some persons. I am prepared to maintain and to prove all that $I$ have advanced,-and more, should more be necessary. I have the honour to be, Sir, your obedient servant,

September 6, 1836.

An Old University-Man.

DR. SIGMOND AND DR. GOLDING.

To the Editor of THE LANCET.

SIR :-On my return to town I had an opportunity of perusing the last number of your periodical, which contains an outline of an address circulated amongst the Governors of the Charing-cross Hospital, by Mr. Pettigrew, in consequence of the extraordinary proceedings of a Committee appointed to enquire into the state of the hospital. That Committee, usurping the power of the Governors, has thought fit to dispense with my services as physician to the hospital, and as Mr. Pettigrew has more than once mentioned my name in the course of his observations, $I$ have to request that you will in a future number do me the kindness to insert an address, which I will take the earliest moment to forward to you.

That I have supported Mr. Pettigrew throughout a most arduous and difficult task, is a subject of self-congratulation, nor do $I$ in the slightest degree regret that $I$ am no longer to associate with individuals whose conduct I have had occasion most severely to censure before that Committee, and with whom I declared I could hold no communication whatever.

Mr. Pettigrew has explained to you the nature of a transaction between himself and Mr. Howship, of which I had, two years before, accidentally heard, but which was then positively denied. It appears that this transaction was thoroughly known to Dr. Golding, to Dr. Shearman, and to Mr. Robertson, in the month of November, but it was not communicated to me, their colleague, until the month of May, and then in consequence only of some dizsensions that had arisen; even then no open, straight-forward course was pursued, but I saw Mr, Pettir grew assailed with provocations and un. manly persecution, which excited in $\mathbf{m y}$ mind a more anxious desire to defend a colleague whom $I$ had always found zealous; active, fand honourable.

I can only now thate that $I$ give my most willing testimony to his observations on the mismanagement of the hospital, and that I purpose laying before you the details of my own statement, made to the Committee, on various points connected with the Institution. I have only now time to request that you will allow me; thus to return my thanks to the different members of the profession, who, in consequence of that which has appeared in your pages, have done me the honour to express, in various forms, their kind feeling towards me; many individuals, to whom I did not know that my name had reached, have in the warmest manner exhibited to me the demonstration of their sense of the annoyance to which I have been subjected, and have volunteered to assist my endeavours to root out the miserable system pursued at the Charing-cross Hospital.

I feel convinced that the medical profession will acknowledge, when all the facts are laid before them, that $I$ have never acted inconsistently with the dignity and honour of a science which $I$ have cultivated with ardour and with pleasure, because it has introduced me to a number of intellectual individuals, in whose society my happiest hours are past. I have the honour to be, Sir, your obedient servant,

G. G. SiGMOND, M.D.

24, Dover-street, Sep. 6, 1836.

\section{DEFENCE OF DR. GOLDING.}

\section{To the Editor of THE LANCET.}

SIR:-There is no part of your public life that has gained you greater credit than the vehement and constant warfare you have waged against those who employ appeals to the benevolence of our countrymen as mere stepping-stones to their own fortune and aggrandisement; nor does any one dispute with you that, in numerous instances, Medical Societies are so managed, as to conduce to little else than the selfish ends of their promoters.

But all rules have exceptions, and it is not fair to designate the Charing-Cross Hospital as a "place of traffic in human misery, in disease and death," unless you had evidence before you, touching the particular case-unless you had been yourself, or sent some credible persons, to examine the place, and the mode in which it is conducted. The terms of your censure are so metaphorical, that $I$ camnot precisely determine what you mean to imply; but taking the most gentle interpretation, it may be presumed you assert, that the hospital does not afford

$$
3 \mathrm{G}_{2}
$$


any material relief to the sick poor, or that it does not afford so much as it might be made to do by a different administration.

If you say anything, you say this; but,.I assure you, you cannot sustain it by an appeal to evidence. 1st. The hospital is a clean, well-ventilated building, having wider wards than any other hospital in London; it is furnished with excellent beds and bedding, and the diet is unexceptionable. That alone is enough to ensure much material relief, but the efficacy of the medical and surgical treatment is secured by the nurses being carefully selected and constantly subjected to the visits, night and day, of the director; and (previous to the recent quarrels) by a full record being kept of all the cases, their treatment and termination-which book is open to the inspection of any one-the attendance of the physicians and surgeons has been frequent, regular, and punctual. Now, throw away your. suspicions as to the motives that actuated the formation and continuance of the hospital, and your opinions as to the merits and demerits of the medical men. Can you deny that good diet, lodging, and regular attendance, are not boons to the diseased?

Let us next enquire whether more good might be effected by a different administration. I will not say that a better medical appointment might not have been made, becanse, of course, the concours would have ensured the services of more brilliant talents, but, taking matters as they are, I believe I may refer you to the book just mentioned, to shew that the Charing-Cross Hospital practice has not been inferior in sanative effects to that of contemporary establishments; and the arrangements of its pecuniary affairs has been the astonishment of every one who has glanced at them. Without entering into minor details, reckon the money collected, deduct the current expences of even the smallest dispensary in London, and look at the building. The hospital had numerous enemies, but I never heard any one deny that the most judicious economy had been used throughout, and that this had been introduced in consequence of the Governors adopting very generally the plans and suggestions of Dr. Golding.

A different inference might be formed from the statements of your correspondent, Mr. Pettigrew ; but, without controverting his assertions, I think it will be easy to them that he has very trivial grounds for his very serious attack. The force of his affirmations is blunted to impotence by the circumstance that, allowing all he says to be unexaggerated, every assertion tells, with equal force, to criminate himself, to injure that character which he prizes dearer than life. For allowing Dr. Golding to be "cruel," "tyrannous," and "revolting in his manners"-allowing him and Dr. Shear- man to be men of " convenient memories"giving all credit to the sensitive Moflat and to Swemmer-granting that the want of bandages (flannel, 18-tailed and complicated), of an operating table, a pulley, and a bolt, are serious grievances, how came Mr. Pettigrew to associate with such base colleagues for 14 years, and how came he to submit to the want of what he thinks necessary to his patients? Should he not have exposed the inhumanity of the Director before; should he not instantly have applied for what was right for his patients, and, in case of a refusal, resigned indignantly, nor waited until he was turned out before he made public disclosures? The hospital may be an infamons Job, "but the Job has cut Mr. Pettigrew, not he the Job." He clung to it with long and ardent attachment.

The force of this recoil of Mr. Pettigrew's accusations on himself is increased by the fact that he did not merely tolerate his col. leagues. He lauded the man of revolting manners to the skies in the dedication to a pamphlet on Hydrophobia. Mr. P. "eagerly embraces" the opportunity afforded by that publication, "to record the regard and esteem he entertains for Dr. Golding personally, and his admiration of his principles and zeal," and talks of "his unwearied exertions" and "philanthropic labours." Further, Mr. Pettigrew was one who subscribed, last autumn, to have a bust of the doctor placed in the hospital, which was erected with the usual eulogia by all his colleagues.

But the vindication of Dr. Golding and his hospital would not be complete by merely proving that his accuser has tolerated his faults, or participated in them. I wish to show that he deserves no blame.

1st. As to his measures, so far from their being revolting, I have always considered them remarkably quiet and gentlemanly. He pretends to no effect, he certainly affeets no particular kindness and softness to pa. tients, nor makes any meretricious attempts to appear profound. But he has a manly, direct, easy method of conversation, not unseasoned with humour, and not the less agreeable, because he displays no inclination to shine. This, it is true, is a matter of taste; but I may confidently appeal to the many members of our profession who have visited the hospital, and conferred with the doctor, which of the two opinions is most correct.

2ndly. As to Dr. Golding's opposition to the union with King's College, it may be urged that a signal want of success has attended this institution in comparison with its rival-that much public advantage is derived from multiplying schools as far as possible, in order to ensure competitionthat his attempts to found an hospital, in which the welfare of the patients was more subsidiary to the instruction of pupils, must 
have been frustrated by a connection where the school was the manifest object; and that he had the recorded opinion of Mr. Pettigrew, (given though before the golden vision of making $£ 500$ by the surgical practice, and saving the school from sinking, by his anatomical lectures, was dissolved,) that such an union was inexpedient. Now these were sufficient reasons to make the director decline the "vast accession of strength," " the considerable increase of funds, the connection of the highest respectability, and the deserved professional emolument," which Mr. Pettigrew, after failing th himself to form a school, so confidently anticipates.

3rdly. Any one who knows any thing about an hospital, knows that you can always find a few dissatisfied patients, some pupils who love (as is natural to youth) an opportunity of finding fault with their superiors, and making a party; and nurses who are delighted with abusing those who keep them in order. But Mr. Pettigrew's cases are strangely selected. Moffat is a curious exception to human nature, if, merely because he had received a hint to go out, and that after Mr. P. had told him not to mind such hints, he rushed forth from a comfortable bed to wander in the streets till three in the morning, without a sixpence; and the circumstance, that the German who writes such good English forgets his own name (for this is Schwemmer, not Swemmer), might have excited a suspicion in Mr. P.'s mind that some enemy to the director had dictated the letter.

4thly. The details of economy always appear petty and mean; yet every man is aware that great accumulations are made by minor savings. The shilling deposit on the crutch will seem to the public foolish parsimony; but those acquainted with the habits of the poor, are aware how often crutches, splints, \&c., being taken away are not returned, and that they amount in the end to something considerable; nor can the instance of individual hardship affect the general expediency of the rule. In other things of the same nature $I$ think that all the medical profession, to which Mr. Pettigrew appeals, will confirm the decision of the committee that his charges are frivolous. Operations are not so numerous as to pre. clude the surgeon from using his own instruments (which, in fact, is the rule of the hospital), an operating table cannot be very essential, since private operations are performed on any table; and, in fact, the thing is a form. The occasional want of a bandage also may have occurred, but such complaints are trivial if made of themselves. If they are brought forward as extreme cases, showing general deficiency in the material of the hospital, they are worthy of attention. But while the general appearance of the hospital patients, and their attendants, is such as $I$ have seen, and such as any one may see who chooses to go there, (and, let it be remembered, the wards have always been open to inspection,) the appointment of a cook who has attempted suicide, or of a nurse who has had a fit, can never be thought grounds of serious censure against the director.

The word " director" brings me to the conclusion of my observations. It may in your ears have a bad sound. But he is only a director to do temporarily what is afterwards to be continued or altered by the governors, who have sufficiently frequent meetings, and he is strictly responsible. Now, those who know how slowly and feebly committees act, how much of injustice they perpetrate collectively, which they would not do individually, and how certainly one persevering man (a treasurer or a secretary) can manage the rest, will agree with me that one individual, on whom rests an entire responsibility, and on whose actions all eyes rest, is a most useful officer, and one from whom less.jobbing is to be expected than from any clique. The success of the Charing-Cross Hospital is a proof of this opinion.

One word more. The committee, it is said, are personal friends of Dr. Goldirg. $\mathrm{Be}$ it so. Men engaged in any work of charity are liable to become friends, but of this committee some must also be friends of Mr. Pettigrew, since at their hands he received his appointment.

I have thought proper to parry an attack made against a man $I$ esteem, and an institution $I$ approve, but $I$ have no wish to thrust again. The industry of Mr. Pettigrew, and his anxiety for distinction, I shall always admire. I am, Sir, your obedient servant,

\section{Bolt-court, Sept. 5, 1836.}

Greville Jones,$$
\text { Bolt-court, Sept. 5, } 1836 .
$$

CORRECTION OF

\section{ERRORS IN STATISTICS AT THE}

\section{BRITISH ASSOCIATION.}

\section{To the Editor of THE LANceT.}

SIR :-At the late meeting of the British Association, there were made some remarks on the Statistics of Mortality in Britain, wh ch are not supported by the facts adduced. You have at different times done me the favour to insert in THE LANCET, the conclusions which I have drawn from the same facts; and I trust that you will now allow me the opportunity of defending my conclusions, by explaining the nature of the errors contained in the opposing statements. 